\title{
AC Breakdown Strength of a Natural Ester Transformer Liquid under Accelerated Thermal Ageing
}

DOI:

10.1109/CEIDP.2016.7785473

\section{Document Version}

Accepted author manuscript

Link to publication record in Manchester Research Explorer

\section{Citation for published version (APA):}

Wang, Z., Liu, Q., \& Lu, Q. (2017). AC Breakdown Strength of a Natural Ester Transformer Liquid under Accelerated Thermal Ageing. In Conference on Electrical Insulation and Dielectric Phenomena 2016 (IEEE Transactions on Dielectrics and Electrical Insulation). https://doi.org/10.1109/CEIDP.2016.7785473

\section{Published in:}

Conference on Electrical Insulation and Dielectric Phenomena 2016

\section{Citing this paper}

Please note that where the full-text provided on Manchester Research Explorer is the Author Accepted Manuscript or Proof version this may differ from the final Published version. If citing, it is advised that you check and use the publisher's definitive version.

\section{General rights}

Copyright and moral rights for the publications made accessible in the Research Explorer are retained by the authors and/or other copyright owners and it is a condition of accessing publications that users recognise and abide by the legal requirements associated with these rights.

\section{Takedown policy}

If you believe that this document breaches copyright please refer to the University of Manchester's Takedown Procedures [http://man.ac.uk/04Y6Bo] or contact uml.scholarlycommunications@manchester.ac.uk providing relevant details, so we can investigate your claim.

\section{OPEN ACCESS}




\title{
AC Breakdown Strength of a Natural Ester Transformer Liquid under Accelerated Thermal Ageing
}

\author{
W. Lu, Q. Liu and Z.D. Wang \\ The University of Manchester \\ Oxford Road \\ Manchester, M13 9PL UK
}

\begin{abstract}
In recent years, there is an increasing interest in applying natural esters as the alternative to mineral oils in large power transformers. But the low resistance to oxidation/gelling process poses a challenge for applying natural esters in freebreathing transformers. Some previous studies presented the gelling/oxidation behaviour of natural esters in terms of physical and chemical properties. There is a lack of study considering the electrical performance of natural ester during the gelling process. In this paper, the $\mathrm{AC}$ breakdown strength of a natural ester from liquid state to totally gelled state was determined. Test cells with a $1 \mathrm{~mm}$ sphere-sphere electrode gap were used to hold ester samples. The ester samples and the test cell were aged together in an air-circulating oven at $120{ }^{\circ} \mathrm{C}$. Dynamic viscosity of the ester samples was also measured to monitor the oxidation/gelling process. Results showed that dynamic viscosity of the natural ester increases more than 100 times during the gelling process. But unlike the rapidly changing physical parameter, AC breakdown strength of the natural ester remains stable during the whole ageing process till the natural ester turns into totally gelled form.
\end{abstract}

\section{INTRODUCTION}

Natural esters derived from natural plants such as vegetable seeds are increasingly considered as alternatives to conventional mineral oils used in transformers, due to their environmentally friendly and less flammable properties [1, 2]. To date in Europe, North America and worldwide, natural ester has been widely applied in sealed distribution and traction transformers [3]. Moreover, there is an increasing interest in applying natural ester in high voltage power transformers, e.g. in April 2013, the world's largest natural ester immersed 300 MVA, $380 \mathrm{kV}$ power transformer was successfully commissioned in Bruchsal, Germany [4].

Different from the ageing of mineral oils, natural esters do not generate sludge during gelling/oxidation, but instead polymerize gradually and lead to an increment of acidity and viscosity [5]. In the worst case, thin films of natural ester left on the surface of windings in transformers might oxidize to gelled forms during manufacture or transportation if oxygen is presented. These thin films of gelled natural ester could inhibit mechanical operation and increase power factor of coil $[6,7]$. Therefore it is still a technical challenge to apply natural ester in free-breathing transformers.

Facing toward the further application in free-breathing transformers, the gelling/oxidation process of natural ester should be studied. In our previous paper [8], gelling/oxidation behaviours of thin films of a natural ester were investigated under accelerated thermal ageing at $120{ }^{\circ} \mathrm{C}$. Total acid number and dynamic viscosity were measured periodically to monitor the gelling progress. The thickness (i.e. volume/surface ratio in a cylindrical cell) of the natural ester samples ranges from 1 $\mathrm{mm}$ to $20 \mathrm{~mm}$. Results showed that both viscosity and acidity are reliable indicators to assess gelling/oxidation behaviour of natural esters from initial liquid phase to eventually gelled form. In addition to ageing temperature, film thickness has a significant influence on the gelling/oxidation behaviour of the natural ester, i.e. the thinner the film is, the faster the gelling speed will be, as shown in Fig. 1 [8]. However, there is no publication describing the electrical performance of natural ester when it is turning to gelled form.

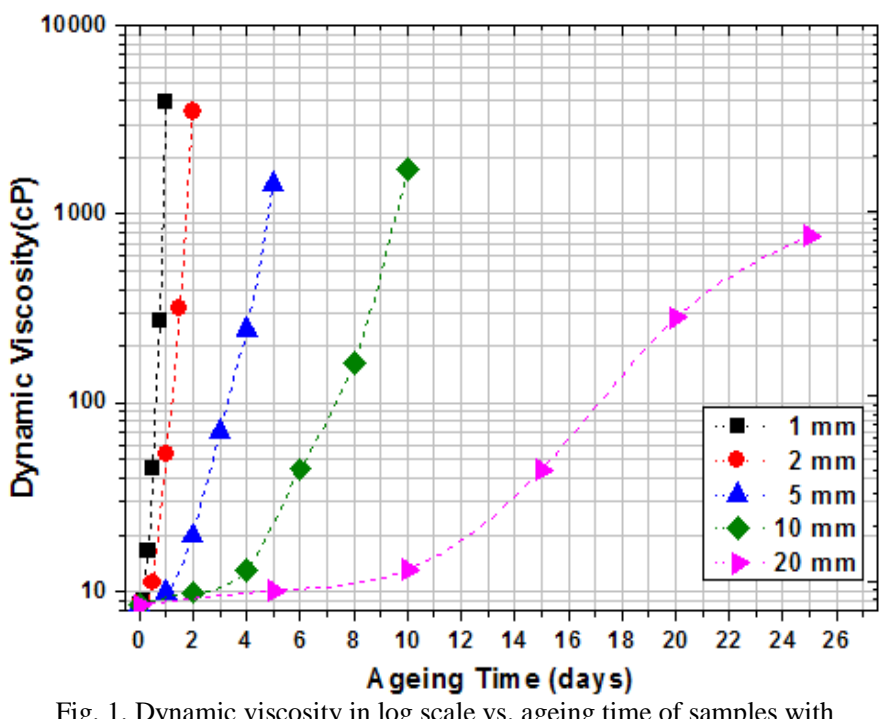

Fig. 1. Dynamic viscosity in log scale vs. ageing time of samples with different film thicknesses at test temperature of $90{ }^{\circ} \mathrm{C}[8]$.

In this paper, the AC breakdown voltage/strength of a natural ester was measured periodically where the natural ester is aged from fresh liquid condition to totally gelled form. Physical parameter, i.e. dynamic viscosity of the natural ester was also measured during the ageing process. The accelerated ageing tests were carried out at $120{ }^{\circ} \mathrm{C}$. A sphere-sphere electrode system with a gap distance of $1 \mathrm{~mm}$ was used for the breakdown tests. 


\section{EXPERIMENTAL DESCRIPTIONS}

\section{A. Materials}

A natural ester liquid Envirotemp FR3 produced by Cargill was investigated in this paper. The basic properties of this natural ester were described in the previous publications [4, 9]. Ester samples were directly taken from sealed barrels, then filtered through a $0.2 \mathrm{~mm}$ membrane unit and lastly degassed and dried in a vacuum oven under $500 \mathrm{~Pa}$ at $85{ }^{\circ} \mathrm{C}$ for over 72 hours. After the pre-processing procedure, the cumulative number of particles with diameter larger than $5 \mu \mathrm{m}$ is less than 500 per $100 \mathrm{ml}$, as shown in Fig. 2. The relative humidity is less than $10 \%$ for the processed ester samples.

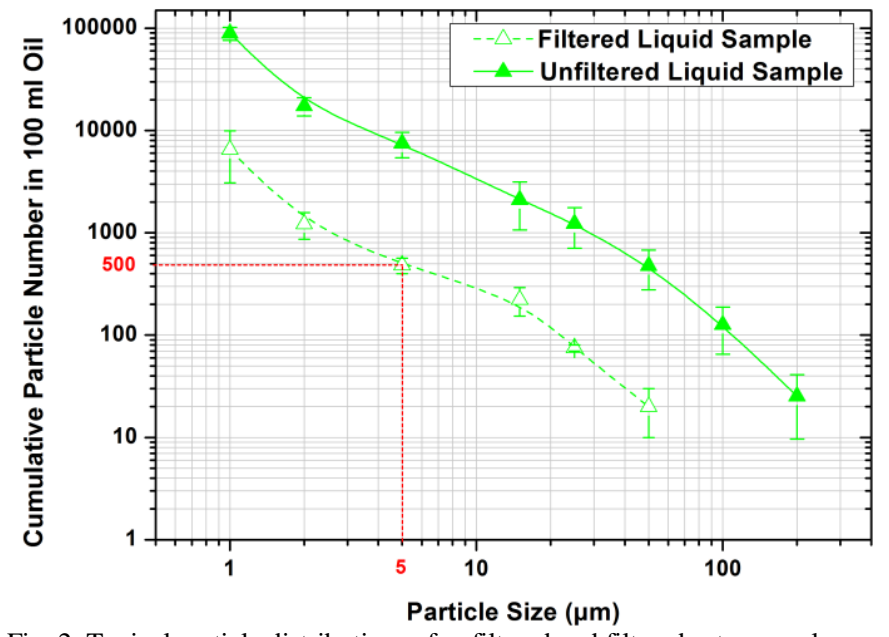

Fig. 2. Typical particle distributions of unfiltered and filtered ester samples.

\section{B. Arrangement of Accelerated Thermal Ageing}

A specially designed cylindrical test cell was used to hold the ester samples and the sphere-sphere electrode system. The cross section view of the test cell is shown in Fig. 3. Side walls and bottom of the test cell were made of PTFE in order to facilitate the thermal ageing at high temperature. The sphere electrode was made of brass, having a diameter of $12.5 \mathrm{~mm}$. Gap distance between the electrodes was set to $1 \mathrm{~mm}$. Ester samples were prepared with the same volume/surface ratio of $20 \mathrm{~mm}$ in multiple test cells to allow measuring parameters periodically.

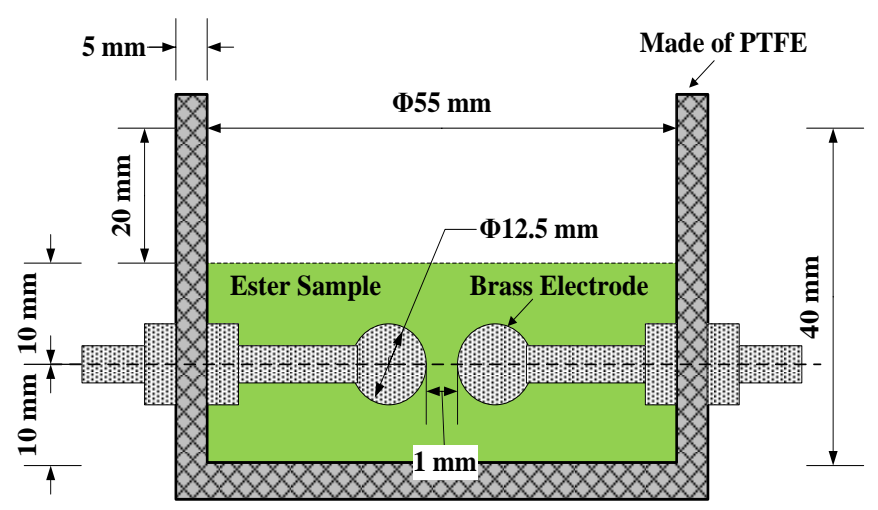

Fig. 3. Cross section view of the specially designed test cell.
After filled with processed ester samples, all test cells were put into an air-circulating oven for accelerated thermal ageing at $120{ }^{\circ} \mathrm{C}$. The thermal ageing tests were carried out for up to 30 days, till the ester sample turned to totally gelled form.

In order to monitor the ageing process, dynamic viscosity of the ester samples was also measured for every 5 days of ageing. A Brookfield DV-II+ Pro viscometer was used to measure dynamic viscosity of samples at test temperatures ranging from $20{ }^{\circ} \mathrm{C}$ to $90{ }^{\circ} \mathrm{C}$. The unit of dynamic viscosity is expressed as $\mathrm{cP}(1 \mathrm{cP}=0.001 \mathrm{~Pa} \cdot \mathrm{s})$. Initial dynamic viscosity of the new natural ester was recorded prior to ageing experiments to be used as the benchmark.

\section{Breakdown Test Procedure}

The test setup for measuring the breakdown voltage of ester samples is shown in Fig. 4. A step-up transformer with a maximum voltage of $70 \mathrm{kV}$ was used to provide the standard $50 \mathrm{~Hz}$ AC voltage to the test cell. The actual applied voltage between the electrodes was measured by using a voltage divider and an oscilloscope. Rising voltage method was used in the breakdown tests. The applied voltage was increased continuously from $0 \mathrm{kV}$ until a breakdown occurred. For every 5 days of ageing period, breakdown voltages of 10 test cells which already contained the aged ester samples were measured.

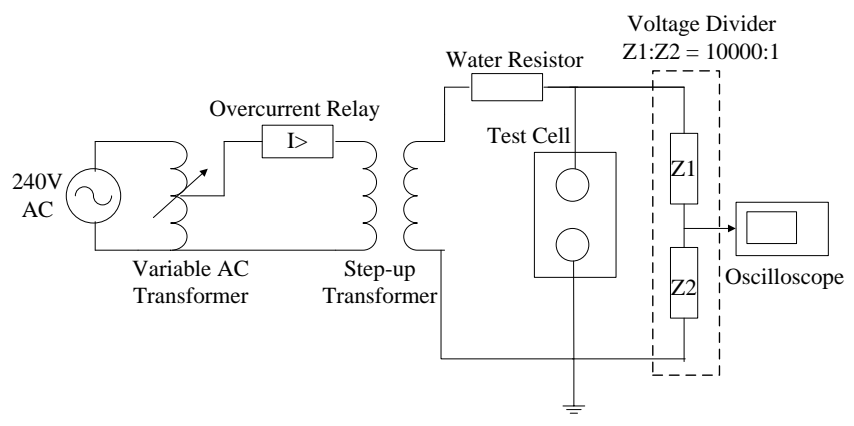

Fig. 4. Sketch of test circuit.

It was noticed that the gap distance of the test cell might change slightly after the ageing experiments, therefore the breakdown results were converted to breakdown strength, i.e. breakdown voltage divided by the actual gap distance, in terms of $\mathrm{kV} / \mathrm{mm}$. After the ageing experiments, an image of the test cell was taken from top-view. The sphere-sphere gap distance was calibrated from a length reference in the image.

\section{RESUlTS AND DisCUSSIONS}

\section{A. Colour and Appearance}

Fig. 5 shows the changes of colour and appearance of the ester samples with the increase of ageing time. It is indicated that the colour of the natural ester darkens with longer ageing time, i.e. from light green prior to ageing experiments to dark brown after 30 days of ageing. The surface of the ester samples also deforms gradually during the ageing process. 


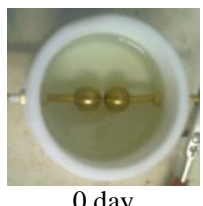

day

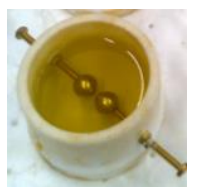

15 days

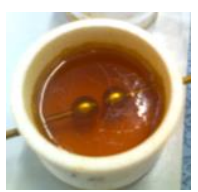

20 days

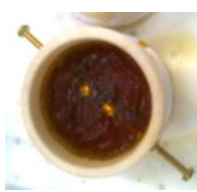

30 days
Fig. 5. Colour of ester samples at different ageing times.

\section{B. Dynamic Viscosity}

The dynamic viscosity of ester samples at different ageing times is shown in Fig. 6 and Fig. 7. Viscosity measurements were obtained from initial liquid phase to almost gelled state at which viscosity measurement could not be carried out. The dynamic viscosity of the natural ester reduces gradually with the increase of test temperature at all the gelling/oxidation stages, whereas the dynamic viscosity of the natural ester increases gradually with ageing time for the whole range of test temperatures. After 25 days of ageing, at the same test temperature, dynamic viscosity of the aged ester samples is more than 100 times higher than that of the new natural ester.

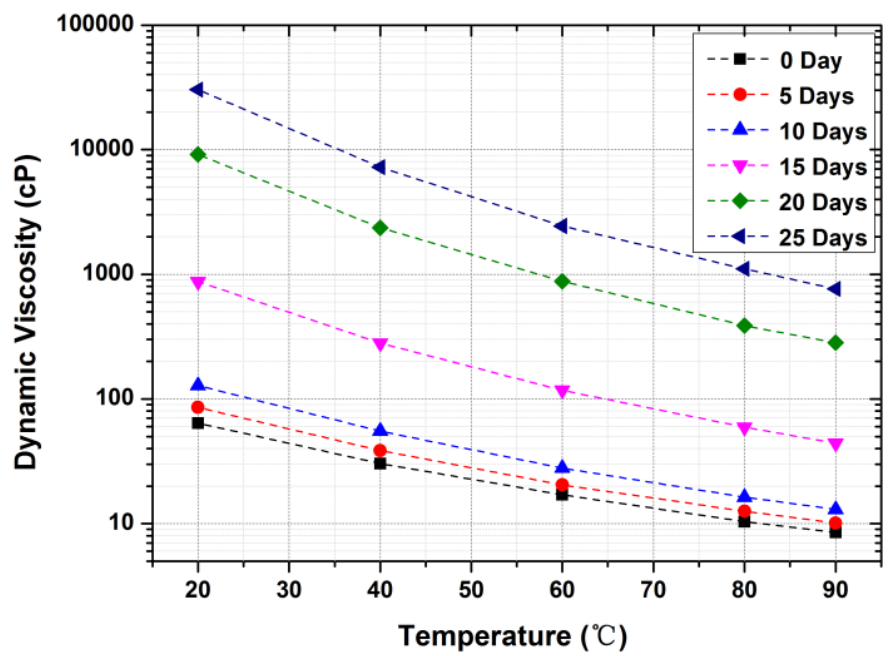

Fig. 6. Dynamic viscosity in log scale vs. test temperature of ester samples at different ageing stages.

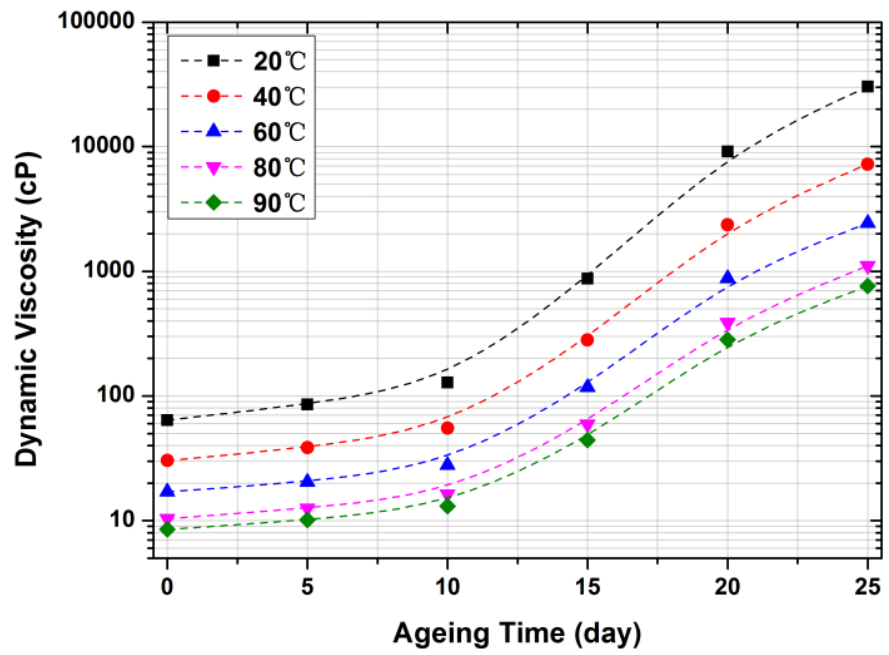

Fig. 7. Dynamic viscosity in log scale vs. ageing time of ester samples at different test temperatures.

\section{B. AC Breakdown Strength $(\mathrm{kV} / \mathrm{mm})$}

In order to statistically analyse the breakdown strength, Weibull distribution was used to fit the breakdown results and to estimate the probability based breakdown strength. A typical Weibull distribution of breakdown results is shown in Fig. 8. Based on Weibull distribution plot in Fig. 8, the breakdown strength at $50 \%$ and $10 \%$ breakdown probability can be obtained, as given in Table I and Fig. 9. Table I and Fig. 9 show that with the increasing of ageing time, the breakdown strength of the ester samples does not change obviously, even when the ester samples turn to totally gelled form after 30 days of ageing.

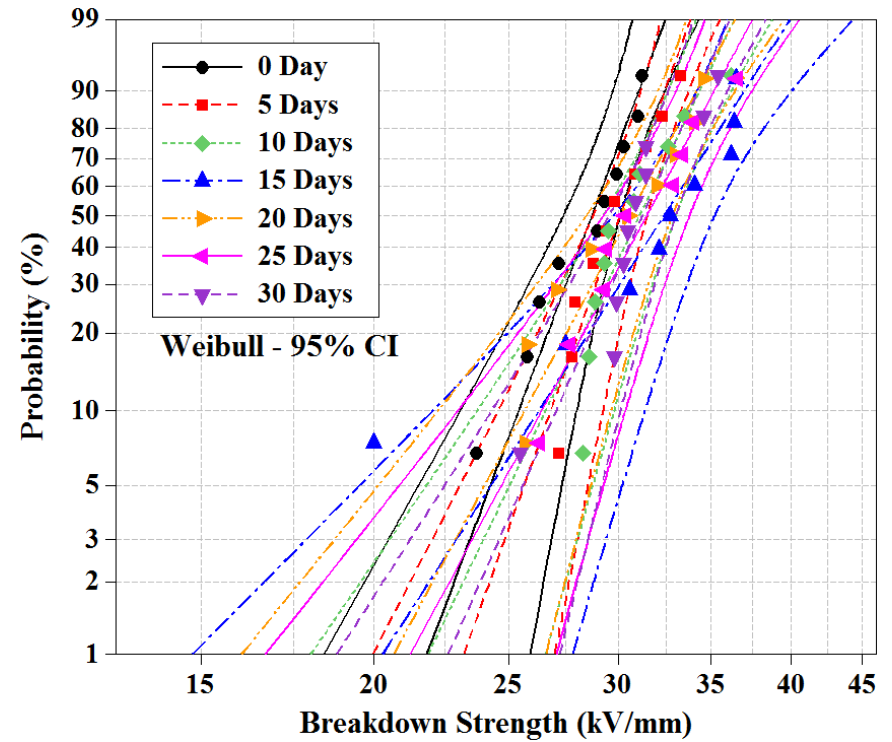

Fig. 8. Weibull distributions of breakdown results obtained at different ageing times. $95 \%$ CI stands for $95 \%$ confidence interval.

TABLE I

Weibull Distribution Parameters of Ester Samples at DifFerent Ageing Times, $\alpha$ Stands for Scale Parameter, $\beta$ Stands for Shape Parameter. Ageing Time (Day)

\begin{tabular}{cccc}
\multicolumn{4}{c}{ Weibull Parameters } \\
$\boldsymbol{\alpha}$ & $\boldsymbol{\beta}$ & U50\% & U10\% \\
29.4 & 15.5 & 28.7 & 25.5 \\
30.8 & 16.3 & 30.1 & 26.9 \\
32.1 & 12.05 & 31.1 & 26.7 \\
33.7 & 9.0 & 32.4 & 26.3 \\
31.6 & 10.8 & 30.6 & 25.7 \\
32.6 & 10.8 & 31.5 & 26.4 \\
32.1 & 13.1 & 31.3 & 27.1 \\
\hline
\end{tabular}

In addition, the correlation between breakdown strength at $50 \%$ probability and dynamic viscosity of the natural ester during the complete gelling/oxidation process is shown in Fig. 10. As a reference, the relationship between viscosity and acidity of natural ester with $20 \mathrm{~mm}$ thickness obtained in [8] is also plotted in Fig. 10. Firstly, the comparison between the viscosity measurement in this paper and previous viscosity results with the same volume/surface ratio of $20 \mathrm{~mm}$ indicates that the gelling process is repeatable and consistent. Secondly, it is shown that the change of breakdown strength is independent of the change of dynamic viscosity and total acid number, i.e. the breakdown strength of natural ester is still stable when viscosity and acidity increases significantly. As a 
summary, the AC breakdown performance of the natural ester is constant even when the physical and chemical performances of natural ester are seriously reduced.

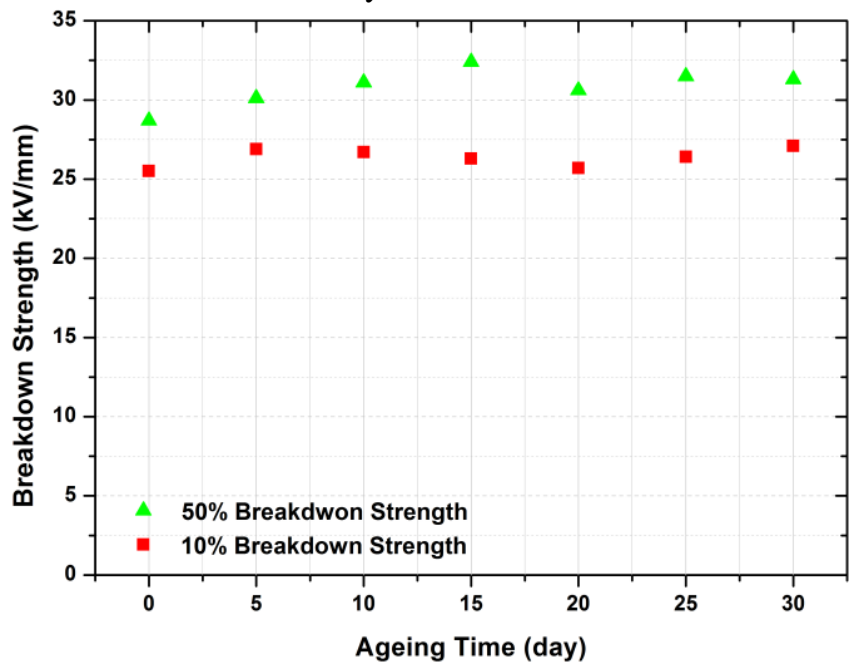

Fig. $9.50 \%$ and $10 \%$ breakdown strengths of ester samples at different ageing times.

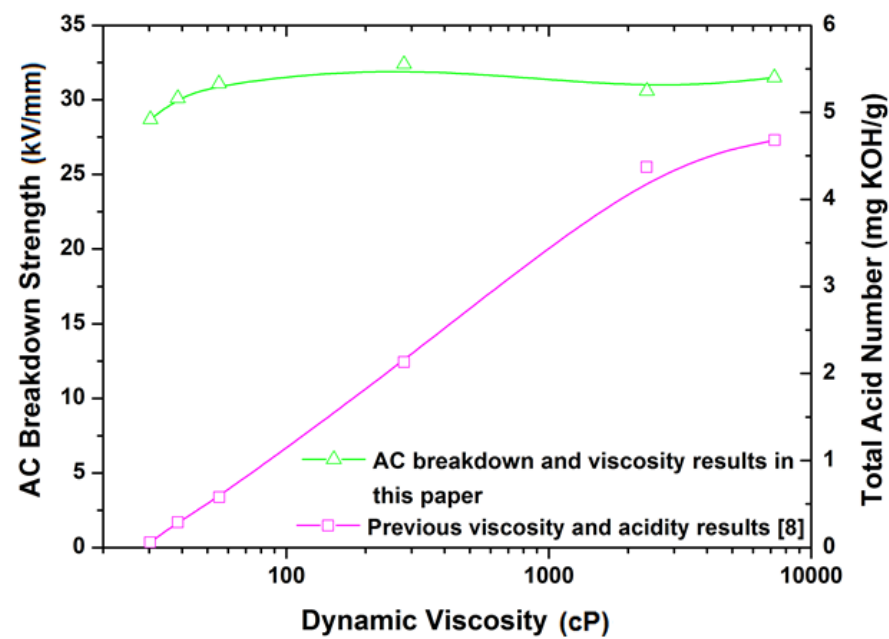

Fig. 10. The relationship between 50\% AC breakdown strength and dynamic viscosity and total acid number measurements in this paper and [8]; viscosity measured at test temperature of $40{ }^{\circ} \mathrm{C}$.

There are a number of factors that could affect the AC breakdown performance of natural ester during the gelling process. As seen in Fig. 5, severe deformation of the gel at the late stage could form micro voids inside the sample, which poses a negative effect on the breakdown voltage [10]. At the same time, some other mechanisms known to influence AC breakdown strength, e.g. particle motion [11], become less significant due to the increased viscosity of natural ester during the gelling process. The increasing viscosity could also make the formation of discharge channel more difficult. In addition, although the acidity increases significantly, those acid by-products might be mainly high molecular weight acids, which are less polar and have less negative impact on the breakdown voltage. There is a trade-off between all these factors, which results in a stabilized AC breakdown performance of natural esters during the gelling process.

\section{CONCLUSIONS}

In this paper, $\mathrm{AC}$ breakdown strength of a natural ester was studied from fresh liquid condition to totally gelled form through accelerated thermal ageing experiments at $120{ }^{\circ} \mathrm{C}$. The ester samples were aged in a test cell with volume/surface ratio of $20 \mathrm{~mm}$. A sphere-sphere electrode system with a gap distance of $1 \mathrm{~mm}$ was used for the breakdown measurements. Dynamic viscosity of the ester samples was also measured periodically as a maker for assessing gelling/oxidation progress of the natural ester.

The results showed that dynamic viscosity of the natural ester increases more than 100 times from initial liquid phase into totally gelled form, whereas the AC breakdown strength of the natural ester remains stable during the whole ageing process till natural ester turns to totally gelled form.

\section{REFERENCES}

[1] L. Lewand, "Laboratory evaluation of several synthetic and agricultural based dielectric liquids," Doble Intern. Client Conf, Boston, US, paper. 5E, 2001.

[2] S. Tenbohlen and M. Koch., "Aging Performance and Moisture Solubility of Vegetable Oils for Power Transformers," IEEE Trans. Power Del, Vol. 25, No.2, pp. 825-830, 2010.

[3] P. Hopkinson, L. Dix, C. P. McShane, H. R. Moore, S. Moore, J. Murphy, T. Prevost, and S. D. Smith, "Progress Report on Natural Esters for Distribution and Power Transformers," IEEE Power \& Energy Society General Meeting (PES), Calgary, Canada, pp. 1-3, 2009.

[4] W. Lu and Q. Liu, "Effect of cellulose particles on impulse breakdown in ester transformer liquids in uniform electric fields," IEEE Trans. Dielectr. Electri. Insul, Vol. 22, No. 5, pp. 2554-2564, 2015.

[5] P. McShane, J. Corkran, K. Rapp, J. Luksich, "Natural ester dielectric fluid development update," IEEE Power \& Energy Society General Meeting (PES), Calgary, Canada, pp.1-6, 26 $6^{\text {th }}-30^{\text {th }}$ July, 2009.

[6] P. Stockton, J. R. Bland, T. McClanahan, J. Wilson, L. Harris, P. McShane, "Natural ester transformer fluids: safety, reliability, environmental performance," IEEE Petroleum and Chemical Industry Technical Conference (PCIC), Calgary, Canada, pp.1-7, 17 $7^{\text {th }}-19^{\text {th }}$ September, 2007.

[7] J. Viertel, K. Ohlsson, and S. Singha, "Thermal aging and degradation of thin films of natural ester dielectric liquids," IEEE Intern. Conf. Dielectr. Liquids (ICDL), Trondheim, Norway, paper 128, $26^{\text {th }}-30^{\text {th }}$ June, 2011.

[8] W. Lu, Q. Liu and Z.D. Wang, "Gelling Behaviour of Natural Ester Transformer Liquid under Thermal Ageing," IEEE Intern. Conf. High Voltage Engineering Application (ICHVE), Shanghai, China, pp. 643$647,17^{\text {th }}-20^{\text {th }}$ Sept, 2012.

[9] Q. Liu and Z.D. Wang, "Streamer characteristic and breakdown in synthetic and natural ester transformer liquids under standard lightning impulse voltage," IEEE Trans. Dielectr. Electri. Insul, Vol. 18, pp. 285294, 2011.

[10] R. P. Joshi, J. Qian, G. Zhao, and J. Gaudet, "Are microbubbles necessary for the breakdown of liquid water subjected to a submicrosecond pulse?," J. Appl. Phys, Vol. 96, No. 9, pp. 5129-5139, 2004.

[11] X. Wang and Z. D. Wang, "Study of dielectric behavior of ester transformer liquids under ac voltage," IEEE Trans. Dielectr. Electri. Insul, Vol. 19, pp. 1916-1925, 2012. 